GEODESY AND CARTOGRAPHY

ISSN 2029-6991 print / ISSN 2029-7009 online

UDC 528.482.3

\title{
MEASURING SHIFTS BASE TO CALIBRATE TEST EQUIPMENT GNSS
}

\author{
Milan Mikoláš ${ }^{1}$, Rostislav Dandoš ${ }^{2}$, Marie Subiková ${ }^{3}$ \\ ${ }^{1}$ Institute of Mining Engineering and Safety, Faculty of Mining and Geology, VSB - Technical University of \\ Ostrava, 17.listopadu 15, CZ 70833 Ostrava, Czech Republic \\ ${ }^{2,3}$ Institute of Geodesy and Mine Surveying, Faculty of Mining and Geology, VSB - Technical University of \\ Ostrava, 17.listopadu 15, CZ 70833 Ostrava, Czech Republic \\ E-mails: ${ }^{1}$ milan.mikolas@vsb.cz (corresponding author); ${ }^{2}$ rostislav.dandos@vsb.cz; ${ }^{3}$ marie.subikova@vsb.cz
}

Received 07 February 2013; accepted 26 February 2013

\begin{abstract}
This article deals with monitoring the stability of the geodetic base Skalka. Introduction of the article briefly describes the history and purpose of the geodetic base Skalka, gradually resulting in the current characteristics of the base. Main part of the article deals with monitoring the stability of points of the inner and partly outer part of the base. The result is the evaluation of performed geodetic works with the assessment of the testing base stability. Identified vertical and horizontal shifts show that the base can be considered stable in terms of both geological and geodetic points of view.
\end{abstract}

Keywords: GNSS, test base Skalka, vertical and horizontal shifts, stability, geodetic works.

Reference to this paper should be made as follows: Mikoláš, M.; Dandoš, R.; Subiková, M. 2013. Measuring shifts base to calibrate test equipment GNSS, Geodesy and Cartography 39(1): 1-6.

\section{Introduction}

The test base Skalka, originally a national satellite station, is located in the village of Kostelní Strrimelice. Originally, this part of the Pecný geodetic observatory was used to observe artificial Earth satellites; since 2000, the base Skalka has been used to test the functionality of GNSS apparatus.

The Skalka base lies mainly on bedrock of the Skalka hill. From the geological point of view, it is a very stable area, but still the base stability must be inspected and surveyed on a regular basis. The base is also measured by the GNSS technology when the survey results are used to draw up calibration protocols. These measurement results are not included in the stability assessment as they are the result of the testing complex "meter + software + GNSS equipment".

When testing the complex, the survey method (the accuracy of centration over points of the outer base, the method of determining the antenna height) and the subsequent data processing are assessed. Based on the size of deviations between reference and determined coordinates, calibration protocols must be drawn up. As the reference coordinates, the coordinates and heights determined using classical geodetic methods with high precision are taken.

\section{History and primary purpose of geodetic base Skalka}

The Geodetic Observatory Skalka, originally the National Satellite Station Skalka, was built as an out-station of the Geodetic Observatory Pecný from 1962 to 1966 (VUGTKa n.d.). The main idea of the station was the utilization of the National Satellite Station for observations of artificial Earth satellites. Originally, the station should be located in the area of the Geodetic Observatory Pecný, but due to filling the observatory with astronomical instruments and observational houses preventing a good view to the horizon, the satellite station was built on a bare hill of Skalka.

The satellite observations at the Skalka station were performed mainly by means of a photogrammetric method using stationary chambers Rb-75, Fig. 1. In 1969 (VUGTKa n.d.), the position of Šankovský Grúň in the eastern Slovakia in relation to a point on Skalka was experimentally determined, using simultaneous observations of artificial Earth satellites. In 1969, the satellite chamber SBG (producer Carl-Zeiss Jena (GDR)) was installed at the observatory. In 1970, the first Czechoslovak laser rangefinder to measure the distances to satellites was tested in this chamber, see Fig. 2. The rangefinder was equipped with a pulsed laser; the optical system of 


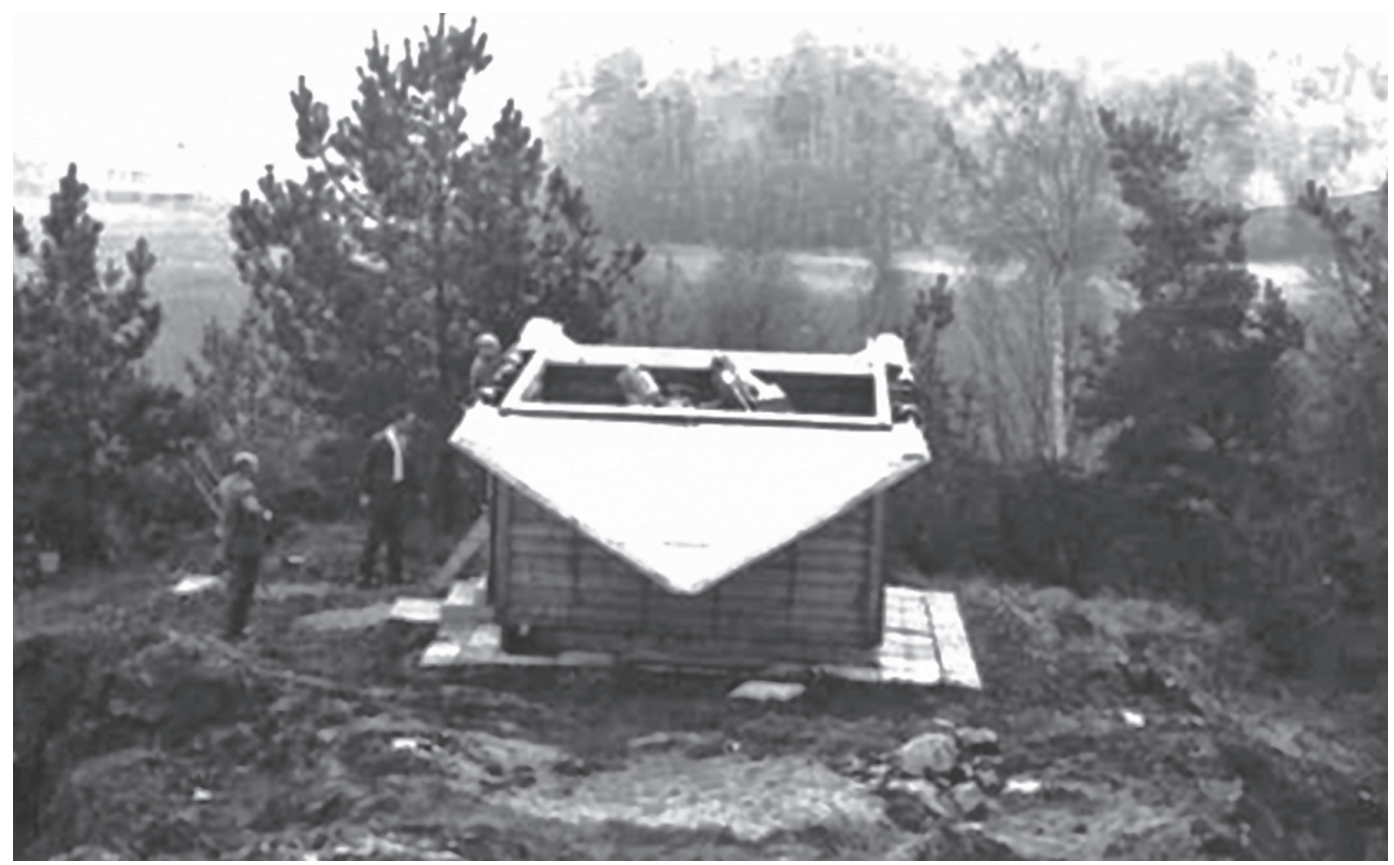

Fig. 1. Air chamber Rb-75 prepared for monitoring artificial Earth satellites

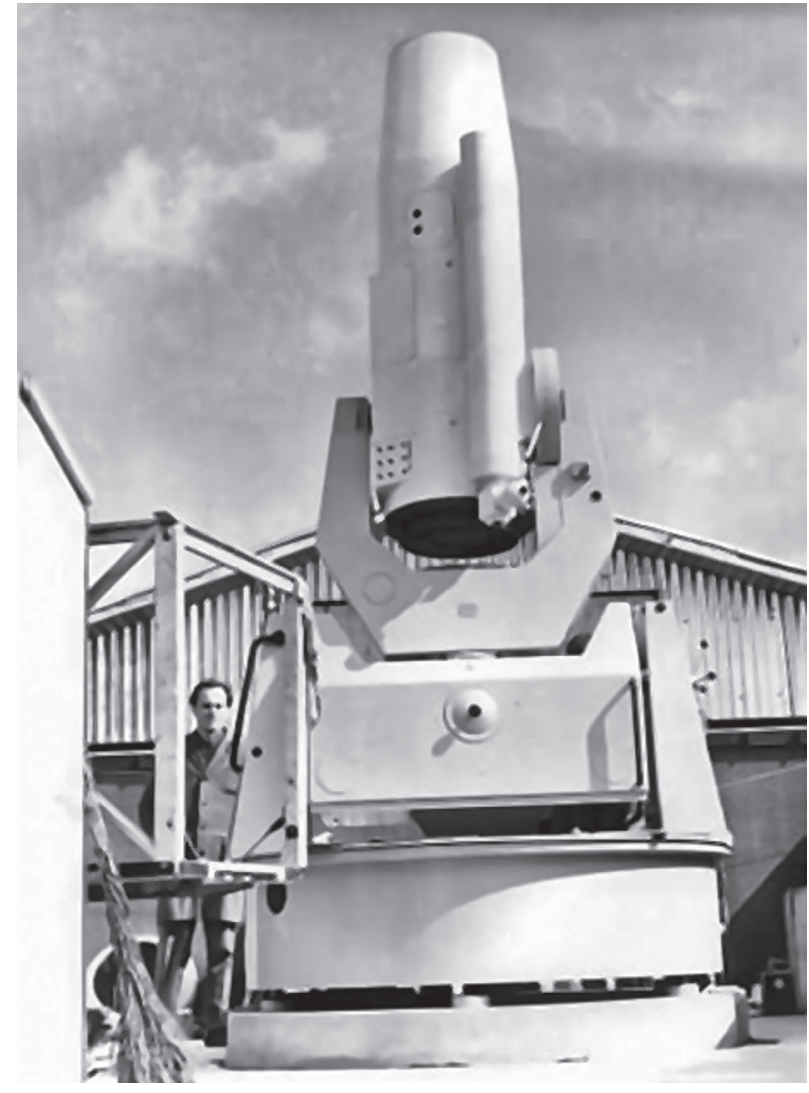

Fig. 2. The SBG chamber for photographic observations of artificial Earth satellites

the chamber was then adapted for receiving reflected signals.

In the years 1984-1989, groups of surveyors from the USSR performed two surveying campaigns of Doppler observations of NNSS Transit navigation satellites on Skalka. The photographic methods for monitoring artificial Earth satellites were completed in 1990. In 1991, the first GPS receiver was obtained, which was installed at the Geodetic Observatory Pecný. The receiver was used for GPS measurements in networks and for experiments only, and thus the primary importance of the Skalka station, i.e. observations of artificial Earth satellites, fell off. Since 1995, permanent GPS observations have been made at the Geodetic Observatory Pecný, performed mainly for the International GNSS Service (IGS). The data from permanent observations is sent e.g. to the GDDIS data centre where the data is used to determine the parameters of rotation of Earth and orbits. In 19992000, the base for testing GNSS equipment was built at the Geodetic Observatory Skalka, and thus its importance for the field of satellite geodesy increased again.

\section{Skalka, test base for GNSS equipment}

Test test base Skalka, Fig. 3, was built in 1999 by the Research Institute of Geodesy, Topography and Cartography in the area of the then Astronomical and Geodetic Observatory. The reason for building the base was the need to authenticate the GPS apparatus functionality, user software as well as the way of measurement by means of the apparatus and the subsequent evaluation of the measured data.

The base is divided into 3 parts - an inner base, outer base and connecting base. Each part of the base has different monumentation and performs different functions as well.

The inner part of the base is formed by five pillars with a forced centring system. The distribution of the pillars network is adapted to suit the requirement to ensure a free horizon above the horizon of about $10^{\circ}$ as well as mutual visibility between the pillars. The coordinates of this part of the base are designed with the greatest 


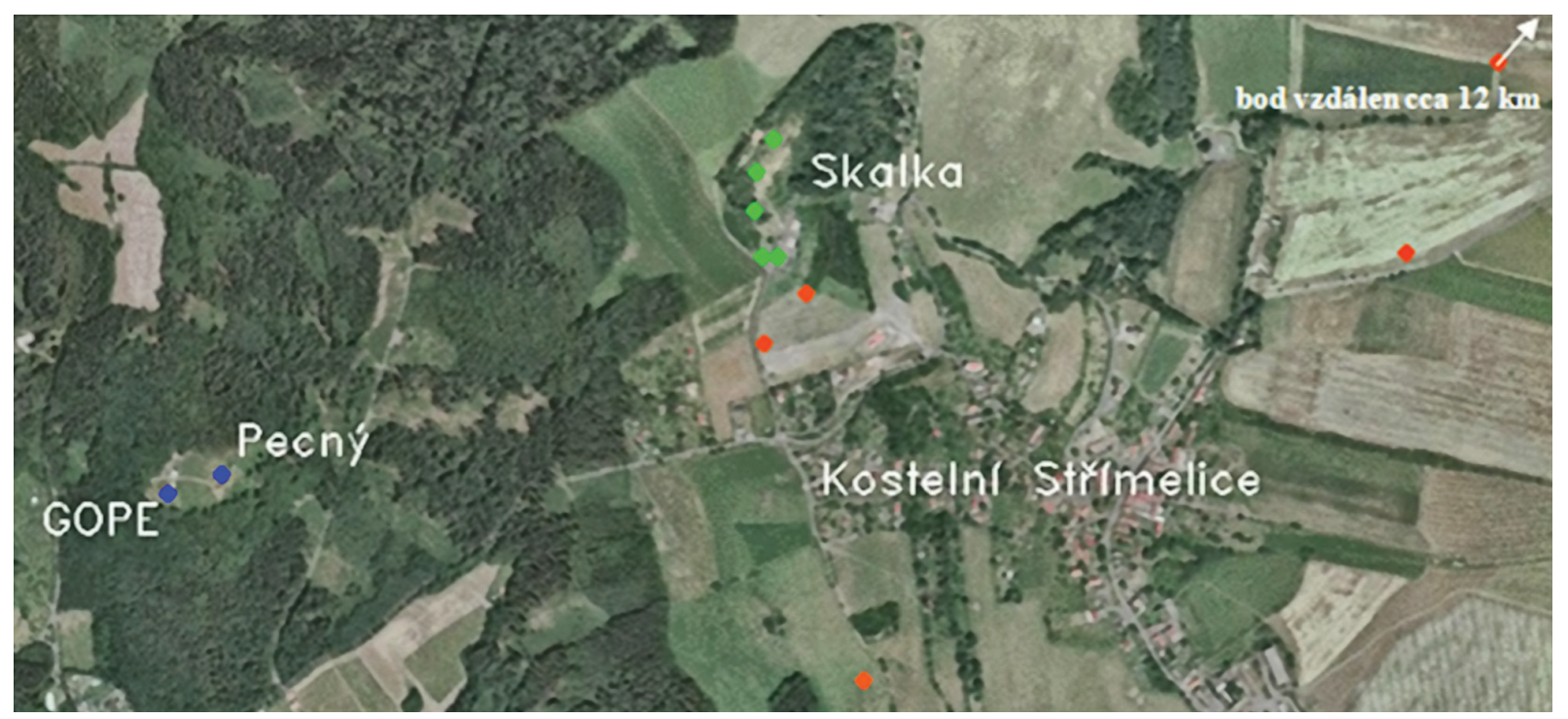

Fig. 3. The distribution of points of the geodetic base Skalka

Points of connecting base

- Points of inner base

- Points of outer "technical" base

possible precision. The maximum distance between the points is $224 \mathrm{~m}$ and the elevation is about $21 \mathrm{~m}$. Two raised pillars spaced about $3 \mathrm{~m}$ are a part of the inner base. These pillars are used to identify positions of phase centres.

The outer base consists of three points of photogrammetric testing field control, levelling point and trigonometric point. The points are monumented with granite beams and fitted with a protective stave. This part of the base is used for verifying practical use of GPS (Vitáskova, Staňková 2004) by means of a tripod and also for measuring the antenna height above the point.

The connecting base consists of the GOPE station of IGS and EUREF permanent services, and then the trigonometric point Pecný (which was used in the first international GPS campaign in Czechoslovakia EUREFCS-H/91 in 1991(Staňková, Černota 2010). The GOPE point is the reference point of the International Terrestrial Reference System (ITRS), which enables accurate connecting test measurements to the current geocentric system. According to (VUGTKb n.d.), the Pecný point is monumented with a granite prism sealed to the base of the surveying tower with concrete. On the upper gallery, there is a central pillar of the tower, which is used for weighing the trigonometric point. Six pillars are symmetrically deployed around the central pillar. The Pecný point is secured with four locking points.

\section{Monitoring base stability}

The term of monitoring stability is meant to be the finding out of horizontal and vertical shifts of points between individual measured stages. Surveying the inner and partly the outer base was made in the years 2000 to 2012. The height point stability was measured in a trigonometric way and also using the precise levelling. The positional stability was verified by means of the radius bar method.
The instrumentation used for surveying was always the most precise one for the certain time and had calibration protocols.

The survey was performed with classical geodetic methods, and for a subsequent calculation and alignment of coordinates, the local coordinate system was used, Fig. 4. The origin of the local coordinate system is in the point $15(y=0 \mathrm{~m}$ and $x=0 \mathrm{~m})$ and the positive $X$-axis is inserted into the point $11(y=0 \mathrm{~m}, x=\mathrm{s} 11,15)$ (Majorník 2008). The starting point for the trigonometric determination of heights is the point $13(z=100 \mathrm{~m})$.

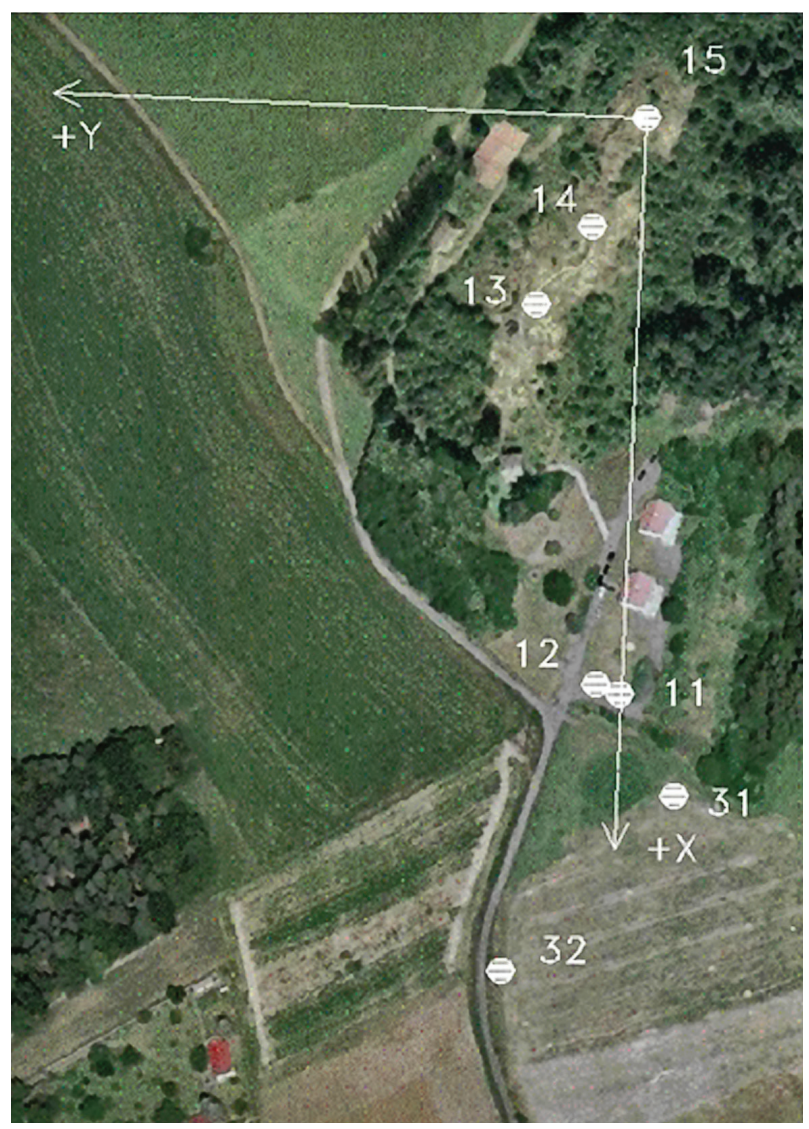

Fig. 4. Local coordinate system with recording positions of points 
The surveying methodology was the same in all phases. For the spatial determination of points, directions were measured (horizontal and vertical ones) in two groups, and lengths were measured bidirectionally. The precise levelling was measured 2 times within the vertical indication field.

Fig. 4 indicates the orientation of axes in the local system as well as the situation with the deployment of surveyed points. Total measurements were performed at all points of the inner base and two closest points of the outer base.

\section{Instrumentation and its accuracy}

The instrumentation used for surveying was always the most precise one for the certain time, and had calibration protocols.

In 2000, according to (Kostelecký 2000), the base was spatially surveyed by Kateřina Plecháčková, a student of the Faculty of Civil Engineering of the Czech Technical University in Prague. The student used the theodolite Wild T3000 with angular accuracy of \pm 5 mgon for angular measurements and for distance measurements - the electro-optical rangefinder Wild DI2000 with the accuracy of length determination of $1 \mathrm{~mm}+1 \mathrm{ppm}$.

In 2001 the base heights were verified by the precise leveling (Kostelecký 2001). The participants of measurements were Ing. Vojtech Pálinkáš and Ing. Jakub Kostelecký. To verify the heights, the levelling device Zeiss Koni 007 and $3 \mathrm{~m}$ long levelling rod graduated by $5 \mathrm{~mm}$, were used.

In 2005 the base was spatially surveyed by Ing. Jiří Lechner, CSc., Ing. Ilya Umnov and Ing. Mark Krátký (Lechner 2005). The total station Leica TCA 2003 was used for measurements with an angular accuracy of \pm 0.15 mgon and length precision of $1 \mathrm{~mm}+1 \mathrm{ppm}$. The base was subsequently measured by means of the precise levelling method using the levelling device Zeiss H05 with an invar levelling rod.

In 2007 the base heights were verified by the method of precise leveling (Lechner et al. 2005). The measurements were made by Ing. Jiří Lechner, CSc., Ing. Ladislav Červinka, Ing. Ilya Umnov and Ing. Jiří Kratochvíl. The levelling device Zeiss H05 was used for measurements. In 2007, the base was measured also by the spatial polar method using the Total Station Leica TCA 2003. The coordinates of 2007 were consistent with the coordinates of 2008, and therefore not listed in Table 1 and in Table 2.

In 2008 a survey was performed by Ivan Majorník, a student of the Faculty of Civil Engineering of the Czech Technical University in Prague, within his bachelorss thesis (Majorník 2008). The student used the universal electrooptical theodolite Leica TCA2003 for surveying. The instrument measures lengths with an accuracy of $1 \mathrm{~mm}$ +1 ppm and angles with an accuracy of \pm 0.15 mgon.

For the last time, the base was surveyed by the authors Ing. Marie Subiková and Ing. Rostislav Dandoš. The survey was performed using the spatial polar method and heights were also verified by the method of precise levelling. For the spatial surveying, the Leica TS30 total station was used, with an accuracy of measuring lengths of $1 \mathrm{~mm}+1 \mathrm{ppm}$ and angular accuracy of \pm 0.05 mgon. To verify the heights, the Leica DNA03 Digital
Levelling Device was used with a moderate mileage error of $\pm 0.2 \mathrm{~mm}$ and a code invar rod.

\section{Monitoring position stability}

It is possible to perform a comparison of positional coordinates of individual stages within the previous measurement (Villim 2011). The comparison was always carried out in relation to the first stage (2000). It is possible to carry out a mutual comparison of individual stage, but due to the fact that Table 2 shows millimetre horizontal shifts in comparison with the measurements performed between 2000 and 2012, there is no need for further comparisons.

Table 1. Coordinates of points in the local network using a classical geodesy method

\begin{tabular}{lllll}
\hline $\begin{array}{l}\text { Point } \\
\text { number } \\
(\mathrm{j})\end{array}$ & $y[\mathrm{~m}]$ & $x[\mathrm{~m}]$ & $y[\mathrm{~m}]$ & $x[\mathrm{~m}]$ \\
\cline { 2 - 5 } 11 & 0,000 & 223,328 & - & - \\
\hline 12 & 2,959 & 222,100 & 2,959 & 222,101 \\
\hline 13 & 37,779 & 74,548 & 37,781 & 74,549 \\
\hline 14 & 17,632 & 42,058 & 17,633 & 42,058 \\
\hline 15 & 0,000 & 0,000 & 0,000 & 0,000 \\
\hline 31 & $-24,691$ & 265,735 & $-24,691$ & 265,735 \\
\hline 32 & 35,200 & 335,022 & 35,200 & 335,022 \\
\hline & & 2008 & & 2012 \\
\hline & $y[\mathrm{~m}]$ & $x[\mathrm{~m}]$ & $y[\mathrm{~m}]$ & $x[\mathrm{~m}]$ \\
\hline 11 & 0,000 & 223,330 & 0 & 223,330 \\
\hline 12 & 2,959 & 222,101 & 2,959 & 222,101 \\
\hline 13 & 37,781 & 74,549 & 37,781 & 74,549 \\
\hline 14 & 17,633 & 42,058 & 17,633 & 42,058 \\
\hline 15 & 0,000 & 0,000 & 0,000 & 0,000 \\
\hline 31 & $-24,691$ & 265,735 & $-24,691$ & 265,735 \\
\hline 32 & 35,200 & 335,022 & 35,200 & 335,022 \\
\hline & & & & \\
\hline & & & & \multicolumn{2}{c}{2005} \\
\hline 15 & & & & \\
\hline
\end{tabular}

The coordinates given in Table 1 are calculated based on the formula (1) and then aligned within the network.

$$
\begin{aligned}
& y_{j}=y_{15}+s_{15, j} \cdot \sin \sigma_{15, j}, \\
& x_{j}=x_{15}+s_{15, j} \cdot \cos \sigma_{15, j},
\end{aligned}
$$

$\sigma$ - bearing from point 15 to point $j$ [gon]; $s_{15, j}-$ horizontal distance between point 15 and point $j[\mathrm{~m}]$; $i$ - marking of measurement phase - year of measurements (2000, 2001, 2005 etc.); $j$ - marking of point.

Differences of coordinates and subsequent total horizontal shift of points are calculated on the basis of the relation (2).

$$
\begin{aligned}
& \Delta y_{2000, i}=y_{i}-y_{2000}, \\
& \Delta y_{2000, i}=x_{i}-x_{2000}, \\
& \Delta p_{2000, i}= \pm \sqrt{y_{2000, i}{ }^{2}+\Delta x_{2000, i}{ }^{2}} .
\end{aligned}
$$


Table 2. Comparison of coordinates in relation to the default stage in 2000

\begin{tabular}{|c|c|c|c|c|c|c|c|c|c|}
\hline \multirow{2}{*}{$\begin{array}{l}\text { Point } \\
\text { number } \\
\text { (j) }\end{array}$} & \multicolumn{3}{|c|}{ 2000-2005 } & \multicolumn{3}{|c|}{$2000-2008$} & \multicolumn{3}{|c|}{ 2000-2012 } \\
\hline & $\begin{array}{l}\Delta y_{2000,2005} \\
{[\mathrm{~mm}]}\end{array}$ & $\begin{array}{l}\Delta x_{2000,2005} \\
{[\mathrm{~mm}]}\end{array}$ & $\begin{array}{l}\Delta p_{2000,2005} \\
{[\mathrm{~mm}]}\end{array}$ & $\begin{array}{l}\Delta y_{2000,2007} \\
{[\mathrm{~mm}]}\end{array}$ & $\begin{array}{l}\Delta x_{2000,2007} \\
{[\mathrm{~mm}]}\end{array}$ & $\begin{array}{l}\Delta p_{2000,2007} \\
{[\mathrm{~mm}]}\end{array}$ & $\begin{array}{l}\Delta y_{2000,2012} \\
{[\mathrm{~mm}]}\end{array}$ & $\begin{array}{l}\Delta x_{2000,2012} \\
{[\mathrm{~mm}]}\end{array}$ & $\begin{array}{l}\Delta p_{2000,2012} \\
{[\mathrm{~mm}]}\end{array}$ \\
\hline 11 & - & - & - & 0,0 & 1,6 & 1,6 & 0,0 & 1,8 & 1,8 \\
\hline 12 & $-0,4$ & 1,4 & 1,5 & $-0,4$ & 1,4 & 1,5 & $-0,5$ & 1,2 & 1,3 \\
\hline 13 & 2,5 & 1,3 & 2,8 & 2,5 & 1,3 & 2,8 & 2,9 & 1,4 & 3,2 \\
\hline 14 & 0,6 & 0,2 & 0,6 & 0,6 & 0,2 & 0,6 & 0,7 & 0,5 & 0,9 \\
\hline 15 & \multicolumn{9}{|c|}{ Fixed point of local system } \\
\hline 31 & 0,0 & 0,0 & 0,0 & 0,0 & 0,0 & 0,0 & 0,2 & $-0,1$ & 0,2 \\
\hline 32 & 0,0 & 0,0 & 0,0 & 0,0 & 0,0 & 0,0 & 0,2 & $-0,5$ & 0,5 \\
\hline
\end{tabular}

\section{Monitoring height stability}

In the area of the base being surveyed, the Vertical Indication Field Pecný is located, which is a part of the levelling line of the second order JacNespeky-Oleška. The levelling line in the area of Skalka is led through individual points of the indication field, through the gravity point and also through levelling marks located on the tops of pillars. The point stability is assessed on the basis of differences in height between the point 13, which is taken as the starting point when determining trigonometric heights, and the other base points.

Table 3. Differences in elevation for individual points in relation to the point 13 determined in a trigonometric way.

\begin{tabular}{|c|c|c|c|c|c|}
\hline \multirow{2}{*}{$\begin{array}{l}\text { Point } \\
\text { num- } \\
\text { ber } \\
\text { (j) }\end{array}$} & \multicolumn{3}{|c|}{$\Delta H_{13, j}^{i(2000)}[\mathrm{m}]$} & \multicolumn{2}{|c|}{$\Delta h_{13, j}^{2000, i}[\mathrm{~mm}]$} \\
\hline & 2000 & 2008 & 2012 & $\begin{array}{l}2000- \\
2008\end{array}$ & $\begin{array}{l}2000- \\
2012\end{array}$ \\
\hline 13 & \multicolumn{5}{|c|}{ Point height taken as starting point for comparison } \\
\hline 11 & $-20,583$ & $-20,583$ & $-20,582$ & 0 & 1 \\
\hline 12 & $-20,462$ & $-20,465$ & $-20,460$ & -3 & 2 \\
\hline 14 & $-0,743$ & $-0,740$ & $-0,744$ & 3 & -1 \\
\hline 15 & $-3,618$ & $-3,617$ & $-3,620$ & 1 & -2 \\
\hline 31 & $-24,941$ & - & $-24,949$ & - & -8 \\
\hline 32 & $-27,362$ & - & $-27,374$ & - & -12 \\
\hline
\end{tabular}

The heights are determined in a trigonometric way based on the relationship (3). The formula ( $4 a, 4 b)$, i.e. the calculation of the difference in elevation between the point 13 and $j$ and the calculation of vertical shifts, is valid for heights determined in a trigonometric way, Table 3, or by the method of precise levelling, Table 4 .

$$
\begin{aligned}
& H_{j}^{i(2000)}=H_{13}+s_{13, j} \cdot \cot g z_{13, j}+v_{p}-v_{S} ; \\
& \Delta H_{13, j}^{i(2000)}=H_{j}-H_{13} ; \\
& \Delta h_{13, j}^{2000, i}=\Delta h_{13, j}^{i}-\Delta h_{13, j}^{, 2000},
\end{aligned}
$$

$H_{j}$ - height of point $j[\mathrm{~m}] ; H_{13}$ - height of point 13 [m]; $s_{13, j}$ - distance between point 13 and determined point $\mathrm{m} j[\mathrm{~m}] ; z_{13, j}$ - zenith angle measured from point 13 to point $j[\mathrm{~m}] ; v_{p}$ - instrument height $[\mathrm{m}] ; v_{s}$ - signal height $[\mathrm{m}]$

Table 4. Differences in elevation of individual points in relation

\begin{tabular}{|c|c|c|c|c|c|}
\hline \multirow{2}{*}{$\begin{array}{l}\text { Point } \\
\text { num- } \\
\text { ber } \\
\text { (j) }\end{array}$} & \multicolumn{4}{|c|}{$\Delta H_{13, j}^{i(2000)}[\mathrm{m}]$} & $\Delta h_{13, j}^{2000, i}[\mathrm{~mm}]$ \\
\hline & 2001 & 2005 & 2007 & 2012 & $\begin{array}{lll}2001- & 2001- & 2001- \\
2005 & 2007 & 2012\end{array}$ \\
\hline
\end{tabular}
to the point 13 , the point heights are determined by the method of precise levelling

13 Point height taken as starting point for comparison

\begin{tabular}{ccccccccc}
\hline 11 & $-20,584$ & $-20,583$ & $-20,584$ & $-20,584$ & 1,5 & $-0,1$ & $-0,3$ \\
\hline 12 & $-20,462$ & $-20,460$ & $-20,462$ & $-20,462$ & 1,6 & 0 & $-0,1$ \\
\hline 14 & $-0,743$ & $-0,742$ & $-0,743$ & $-0,741$ & 0,8 & 0,3 & 2,2 \\
\hline 15 & $-3,617$ & - & - & $-3,617$ & - & - & 0,1 \\
\hline 31 & - & $-24,933$ & - & $-24,936$ & - & - & $-2,4^{*}$ \\
\hline 32 & - & $-27,358$ & $-27,360$ & $-27,360$ & - & $-2^{*}$ & $-1,6^{*}$ \\
\hline
\end{tabular}

Note: The declines marked with ${ }^{*}$ are determined in relation to the stage 2005 .

\section{Conclusions}

This paper describes the way in which the stability of points of the geodetic base Skalka is monitored. The base is part of the Geodetic Observatory Pecný and originally served to observations of artificial Earth satellites. At present, the base is used primarily to testing the GPS apparatus. The testing is performed on the basis of the distance between the determined coordinates and the reference coordinates. 
The base was built in 1999-2000 and since then it has been being regularly measured. Based on these measurements, the stability of the base, horizontal and vertical shifts in relation to the initial stage measured in 2000, is determined. Measurements are always carried out with the latest and most accurate geodetic instruments. Coordinates of base points are calculated in a local system, Fig. 4, and heights are calculated in a trigonometric way in relation to the point 13 and, from the levelling point of view, are related to the vertical indication field which is built on the premises.

Horizontal shifts $\Delta p_{2000, i}$ and vertical shifts $\Delta p_{2000, i}$ vary in the order of $\mathrm{mm}$. A maximum horizontal shift is at the point No. $13-3,2 \mathrm{~mm}$ and a maximum vertical shift is at the point No. $31-2,4 \mathrm{~mm}$.

Vertical shifts were also determined in a trigonometric way, which is a less accurate method, but even so the differences range from -3 to $3 \mathrm{~mm}$. The exception is the points 31 and 32 at which the vertical shift is about $1 \mathrm{~cm}$. This variation may be due to the inaccurate determination of the machine height over the point monumentation of the outer base, as it is not exactly possible to assign the end of the band to the defined point. Given that the points 31 and 32 are monumented by the "classical" geodesic monumentation, the vertical shift could occur during the monitored period as well.

The points inside the base are located on hard bedrock (granite) and it can reasonably be expected that their stability is not compromised in any way. Monitoring the height as well as positional stability shows a max shift $\pm 3 \mathrm{~mm}$ in about 12 years, which are negligible shifts due to the size of the entire base.

\section{References}

Kostelecký, J. 2000. Zaměření testovací základny pro GPS pozemnimi metodami (shrnutí prací provedených v roce 2000), Technická zpráva 1008/2000. Czech Republic. Zdiby: VÚGTK.

Kostelecký, J. 2001. Ověření výšek testovací základny pro GPS pomocí nivelace, Technická zpráva 1015/2001. Czech Republic. Zdiby: VÚGTK.

Lechner, J. 2005. Technická zpráva o polohovém a výškovém měrení v síti geodetických bodu testovací základny pro GPS na geodetické observatoři pecný i skalka - o metrologickém navázání v parametru úhel a délka, Technická zpráva 1086/2005. Czech Republic. Zdiby: VÚGTK.

Lechner, J., et al. 2005. Délkové, výškové a polohové určení geodetické bodové sitě výzkumného ústavu geodetického, topografického a kartografického $v$ areálu skalka, Technická zpráva. Czech Republic. Zdiby: VÚGTK.
Majorník, I. 2008. Sledování stability GPS základny skalka: Bachelor thesis [online], [cited 30 June 2012]. Available from Internet: http://gama.fsv.cvut.cz/ cepek/proj/ bp/2008/ivan-majornik-bp-2008.pdf

Staňková, H.; Černota, P. 2010. Principle of forming and developing geodetic bases in the Czech Republic, Geodesy and Cartography 36(3): 103-112.

http://dx.doi.org/10.3846/gc.2010.17

Villim, A., et al. 2011. Spoločné spracovanie družicových a terestrických meraní v priestorovej sieti pre dopravnúinfraštrukturu, Civil and Enviromental Engineering, v. 7. Slovak Republic. Zilina university.

Vitásková, J.; Staňková, H. 2004. Návody na měření s GPS. Czech Republic. Brno: MZLU.

VUGTKa n.d. Historie observatoře Pecny [online], [cited 16 July 2012]. Available from Internet: http://oko.asu.cas.cz/pecny/ histo.html

VUGTKb n.d. Testovací základna pro GPS [online], [cited 20 July 2012]. Available from Internet: http://oko.asu.cas.cz/ pecny/zgpspol.html

Milan MIKOLÁŠ. Doc. Ing., Ph.D. VŠB - TU Ostrava, Institute of Mining Engineering and Safety, Faculty of Mining and Geology, VSB - Technical University of Ostrava. 17.listopadu 15, CZ 70833 Ostrava, Czech Republic. Ph+420 608533 231, e-mail: milan.mikolas@vsb.cz

Research interests: mining engineering and safety.

Rostislav DANDOŠ. Ing. VŠB - TU Ostrava, Institute of Geodesy and Mine Surveying, Faculty of Mining and Geology, VSB - Technical University of Ostrava, 17.listopadu 15, CZ 708 33 Ostrava, Czech Republic. Ph+420597323326,

e-mail: rostislav.dandos@vsb.cz

Research interests: analysis of possible deformation monitoring of buildings using modern technology.

Marie SUBIKOVÁ. Ing. VŠB - TU Ostrava, Institute of Geodesy and Mine Surveying, Faculty of Mining and Geology, VSB - Technical University of Ostrava, 17.listopadu 15, CZ 708 33 Ostrava, Czech Republic. Ph+420597323326,

e-mail: marie.subikova@vsb.cz

Research interests: this article is part of the dissertation on the topic of building a base for calibration apparatus GNSS. 